\title{
Surfaces
}

\section{Thinking Feminist Thought}

\section{Roundtable 5}

\section{Yung-Hsing $\mathrm{Wu}$}

Volume 7, 1997

\section{LE FÉMINISME HORS DE LUI-MÊME}

FEMINISM BESIDE ITSELF

URI : https://id.erudit.org/iderudit/1064814ar

DOI : https://doi.org/10.7202/1064814ar

Aller au sommaire du numéro

Éditeur(s)

Les Presses de l’Université de Montréal

ISSN

1188-2492 (imprimé)

1200-5320 (numérique)

Découvrir la revue

Citer cet article

Wu, Y.-H. (1997). Thinking Feminist Thought: Roundtable 5. Surfaces, 7.

https://doi.org/10.7202/1064814ar d'utilisation que vous pouvez consulter en ligne.

https://apropos.erudit.org/fr/usagers/politique-dutilisation/ 


\title{
Thinking Feminist Thought Roundtable 5
}

\author{
Yung-Hsing $\mathrm{Wu}$ \\ Indiana University \\ Bloomington
}

Surfaces Vol. VII.115 (v.1.0A - 28/06/1997) - ISSN: 1188-2492

Copyright for texts published in Surfaces remains the property of authors. However, any further publication should be accompanied by an acknowledgement of Surfaces as the place of initial publication.

This piece begins as a reflection on the simple phrase, "feminist thought." It does so because it seems to me that one response to "Feminism Beside Itself" might take not just the form of reflection but might also take (however successfully) thought as an issue for consideration. Of the many paradoxes that have been and continue to be cited around the signifier "feminism," there perhaps is none so basic as the one residing in the phrase "feminist thought." Much used and frequently appealed to, the words "feminist thought" are those that one reads and types easily, words familiar to eyes and fingers alike. They appear in articles, books, and anthologies devoted entirely to feminism as well as in sound bytes and references that cite them in order to take the pulse of contemporary society. But for all this familiarity, there are very profound ways that "feminist thought" is nothing if not unfamiliar, strange, or even contradictory. Grammatically speaking, "feminist" qualifies "thought," it brings to thought the qualities of feminism, but what exactly is the result and logic of this combination? What does thought look like when it encounters feminism? After all, feminism has been one institutional and intellectual place where the very hold 
on thought (and what one understands thought to be) exerted by logocentric culture has been attenuated and complicated.

To put it another way, feminist thought is supposed to be somehow different from the philosophical and epistemological models that have preceded or provided it with some foundation. Not merely comprised of different content or ideas, feminist thought becomes on this account thought/thinking with a difference. Yet this emphasis on difference has frequently resulted in precisely an approach whereby the operating presumption is that feminism knows what difference is. Here the difference of feminist thought becomes its concentration on and inquiry into the question of difference. Difference takes on the quality of that which feminism can and must talk about; difference acquires the status of a subject, of feminism's subject in particular.[ 1 ] As assumptions, these have proven to be dangerous and generative at the same time. Dangerous, in the sense that presuming to know what difference is characterizes feminism and feminist thought as unyielding and dogmatic-as all too certain in its claims and thereby all too inflexible in its agendas. Generative, insofar as a knowledge and awareness of difference has compelled feminism to pay heed to its assumptions about constituency and the politics of representation and community.

Combined, these two concerns with difference-the dangerous and the generative-result in what might be called the dangerous generations of feminist thought. By this I mean that feminism's insistence on difference has made the project of feminist thought a self-threatening and self-perpetuating endeavor. Moreover, the insistence on difference has come increasingly to register as feminism's preoccupation with making a difference and how that difference might or might not be made through thinking.

This last statement should be broken down further. First, to read an insistence on difference as a preoccupation with making a difference suggests an implicit ethics to feminism and to feminist thought specifically. Second, to say that making a difference preoccupies feminism is in many ways to represent feminism as setting out on a journey, with its progress and contributions measured out incrementally. The telos posited by this

Bildungsroman-like journey assumes that there is some definitive point at which feminism will have arrived and know that its job is done. While this kind of narrative can make apparent that feminism has changed and has 
contributed to the changes that have marked history, this kind of understanding is also what enables commentators to coin a phrase like "post-feminism." Third, that feminist thought should have a part in this endeavor returns me to my initial question about the issue and status of thought. Especially in terms of feminism, which has addressed consistently the theory/ practice disjunction, this emphasis on thought is crucial. How does feminist thought-itself presented as different from other modes of thought-contribute to the project of making a difference?

One way to begin to answer this question is to consider the ways in which feminist thought gets conceptualized. In doing so I want to turn my attention to the topic of the last panel "The Futures of Feminism?" The reason for this turn is simple: that panel, or at least its subject, functioned throughout as one of the conference's main preoccupations. On this panel the open-ended, interrogatory "futures" of feminism held out the promise and possibility of making a difference. The "futures" of feminism were in this way always a given; they were expected and anticipated as concerns that the conference would of course have. Chronologically last, these futures nonetheless preceded discussion and conversation.

The impulse of this particular panel, however, was to articulate these possible futures, to be deliberate and specific about the question of what feminism needs, or has yet to do. From characterizing the role of a nowinstitutionalized feminism to asking what relations feminism can or should have with metaphysics, this panel had a double task: to direct attention to the future as well as to consider how to turn that attention into practice, to manifest the future. In this doubled light, that the subject of a "new universalism" should receive a good deal of attention was hardly surprising (my emphasis), as "new" points temporally to the difference that the future might hold for feminism.

More importantly, however, "new" evoked conceptual difference concerning the status of thought and thinking. By that I mean that "new" attests to a process of thinking, to an approach toward thinking that is not solely a matter of reflection nor the resolution of some problem. Earlier I have described feminism taking and thinking of difference as its subject, and indeed that appropriation has been a great part of feminism's impact. Here, however, I am describing a situation in which thinking itself comes under scrutiny. Feminist thought occupies the position of scrutinizing thought in 
order for itself to think. In this way, it takes part in, although is not wholly constrained by, a philosophical discourse that describes the relations between thought and philosophy.

For one, the scrutiny of thought means that feminism must address the limits of the concept. As Theodor Adorno notes in Negative Dialectics, the very idea of the concept belongs to the realm of philosophy even as it poses a threat to philosophizing.[ 2 ] Thus situated, the concept marks the line between philosophy's foundation and its limit, a line that feminism can both respect and cross. Adorno claims-as Kant does in The Critique of Pure Reason-that because knowledge arrived through concepts must be mediated, no concept can be identical with its object. This non-identity, far from being an indication of inadequacy, refers instead to both the concept's limitations and what it does not limit. For Adorno the introduction of such nonidentity means the hope that philosophy can continue conceptualizing, even as it must depend on the concept. I am suggesting that feminist thought, in understanding and regarding thought as a philosophical concept, both provokes a critique and continues an elaboration of thought similar to Adorno's.

Having said that, the question to ask is: by conceptualizing a "new universalism"-described as a project to rethink democracy and the relationship between the universal and the particular-is feminism in a position to make good on that promise of critique and elaboration? Or to put it another way: where does feminist thought need to be in order to think in this manner? This question, by making thought a matter of situation, suggests that both feminism's definition of thought and the definition of feminism have to do with a response to a "call."

I want to characterize here two of the responses to the proposal of new universalism in order to get at more specifically the intersection of thought, feminism, and difference. First, the problem of "new." One comment suggested that the call for new universalism was just that-only a call, neither specific nor particular enough to signify. As such, "new universalism" is too undeveloped, unformed in the sense that it possesses too little specific content that would fill in the outlines of a rethought democracy, or a politics that would pay heed to differences. Put another way, "new universalism" is only a form; it lacks substance and actuality. Feminism could hardly rely on or turn to something that has yet to be formulated or tested. Secondly, if the "new" of "new 
universalism" seems untrustworthy, "universalism" looks even less so-even if, or perhaps exactly because, it is to be modified by some sense of newness. Several participants thus pointed out that the philosophical heritage and underpinnings of universalism -for instance, the abstraction of the subject and the idealization of such formal abstraction-could hardly be forgotten, let alone changed. Not forgetting becomes in this context an injunction to be cautious against the rhetorical appeal of newness and radical change.

What emerges here is not solely a critique of new universalism, but also a situation whereby "new" and "different" are aligned and then turned aside because they cannot be thought specifically. The possibility that new universalism would be different (in all the "right" ways, e.g., in the case of the subject, would new universalism remember that not all subjects are the same) from universalism is held up against the risk that "new" might not be able to intervene concretely enough. Yet this lack of specificity is in some ways exactly the point, since a call for some "new" means the absence of knowable particularity. Because it has not one specific referent (aside from time), this "new" can only be premature and anticipatory. The critique of new universalism-that it is just a call-thus reveals a desire for and anxiety about certainty.

I want to be as clear as I can here. By saying that desire and anxiety underlie the critique of new universalism, I am not suggesting that such a critique is misguided. Nor am I claiming that new universalism is safe or secure from that critique. To do either would be to take sides, with the underlying assumption that feminism's future course is knowable or that one can know better for feminism. Rather, it seems to me that the feminist concern to foreground difference-as an attribute that marks specificities, as a political goal to be sought after and realized, and as an elaboration of thought-allows it to entertain the possibilities of something like a new universalism while maintaining a critical relation to those possibilities. Not simply critical distance, through which feminism might remain, or attempt to remain, untrammeled by new universalism, critical relation here describes a state of affairs in which feminism takes seriously the uncertainty of thought. 


\section{NOTES}

1. This claim holds true more generally for contemporary critical theory as well. It is now a common gesture in theoretical work to mark difference itself as the end: as the end to which theories of political representation should aspire, as well as the end of the subject posed by the Enlightenment.

2. Adorno's notion of the concept constitutes one of his most important responses to Hegel. In particular, Adorno calls the dialectic the concept of Hegelian thought, thus casting the dialectic as a totalizing model of the concept.

Accueil Surfaces | Table des matières | Recherche Surfaces Home Page | Table of Contents | Search

PUM | Livres | Revues | Publications électroniques | Vente et distribution 